Türkiye Tarımsal Araştırmalar Dergisi
dergipark.gov.tr/tutad $\begin{aligned} & \text { Turk J Agric Res } \\ & \text { 2017, 4(2): 143-154 } \\ & \text { O TÜTAD } \\ & \text { ISSN: 2148-2306 } \\ & \text { e-ISSN: 2528-858X } \\ & \text { doi: 10.19159/tutad.292593 }\end{aligned}$

\title{
Çataklı Çayı Havzası Doğu Yakasında Çay Tarımı Yapılan Toprakların Fiziksel, Kimyasal ve Verimlilik Özelliklerinin Belirlenmesi
}

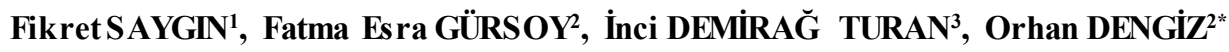 \\ ${ }^{1}$ Karadeniz Tarımsal Araştırma Enstitüsü Müdürlüğ̈̈, Samsun, TÜRKIYY \\ ${ }^{2}$ Ondokuz Mayls Üniversitesi, Ziraat Fakültesi, Toprak Bilimi ve Bitki Besleme Bölümü, Samsun, TÜRKIYE \\ ${ }^{3}$ Giresun Üniversitesi, Fen Edebiyat Fakültesi, Coğrafya Bölümü, Giresun, TÜRKIYYE
}

\begin{abstract}
Geliş Tarihi/Received: 16.02 .2017
Kabul Tarihi/Accepted: 26.04 .2017

*Sorumlu Yazar/Corresponding Author: odengiz@omu.edu.tr

Ö zet: Buçalışma, Çataklı Havzası'nın doğu yakasında çay (Camellia sinensis L.) tarımı yapılan toprakların bazı fiziksel ve kimyasal özellikleri ile besin elementleri durumlarının belirlenmesi amacıyla yapılmıştır. Çalışma alanından farklı eğim, yükseklik ve fizyografik ünite olmak üzere 16 noktadan yüzey ve yüzey altı toplam 32 toprak örneği alınmıştır. $\mathrm{Bu}$ toprakların fiziksel ve kimyasal özelliklerinin (bünye, $\mathrm{pH}, \mathrm{EC}$, kireç, organik madde, $\mathrm{Na}, \mathrm{K}, \mathrm{Ca}, \mathrm{Mg}$ ) yanında verimlilik analizlerini içeren $(\mathrm{N}, \mathrm{P}, \mathrm{K}, \mathrm{Cu}, \mathrm{Zn}, \mathrm{Fe}, \mathrm{Mn}) 16$ farklı parametre analiz edilmiș ve elde edilen sonuçların tanımlayıcı istatistiksel hesaplamaları yapılmıştır. Çalışma alanı yüzey topraklarının kum, kil ve silt miktarı sırasıyla \% 28.40 -77.68, $\%$ 7.60-46.88 ve \% 14.72-34.72; yüzey alt 1 kum, kil ve silt miktarı sirasıyla \% 41.12-81.12, \% 6.88-40.88 ve \% 12-34 olarak bulunmuştur. Yüzey ve yüzey altı için hâkim bünye sınıfı kumlu tındır. Çalışmada yüzey topraklarının pH'ları 3.76-5.63 arasında, yüzey altı topraklarının $\mathrm{pH}$ 'ları ise 3.70-6.32 arasındadır. Toprakların organik madde düzeyleri ise yüzeyde $\%$ 0.61-3.01, yüzey altında ise \% 0.48-4.24 arasında değişmekte olduğu belirlenmiştir. Toprakların makro besin element leri olarak adlandırılan azot, fosfor ve potasyum içeriklerinde, genellikle yetersizlikler belirlenmiş olmasına karşıllı; mikro be sin elementlerinden bakır ve demir içeriklerinde bir problem bulunmazken, çinko ve mangan içeriklerinde yetersizlikler belirlenmiștir.
\end{abstract}

Anahtar Kelimeler: Çay bitkisi, toprak özellikleri, Çataklı Havzası

\section{Determination of Physical, Chemical and Fertility Properties of Soils Used for Tea Cultivation in East Part of the Çataklı River Basin}

\begin{abstract}
The aim of this study was to determine physical, chemical and nutritional status of soils (Camellia sinensis L.) in east side of Çataklı River Basin, in which tea (Camellia sinensis L.) has been cultivated. A total of 32 soil sample were collected from 16 locations including both surface $(0-30 \mathrm{~cm})$ and subsurface $(30-60 \mathrm{~cm})$ while taking slope, elevation and physiographic units into consideration. 16 different soil parameters; texture, $\mathrm{pH}, \mathrm{EC}$, lime, organic material, $\mathrm{Na}, \mathrm{K}, \mathrm{Ca}, \mathrm{Mg}$, $\mathrm{N}, \mathrm{P}, \mathrm{K}, \mathrm{Cu}, \mathrm{Zn}, \mathrm{Fe}$, and $\mathrm{Mn}$ were analyzed and descriptive statistical properties were calculated. According to the results, sand, clay, and silty content of the surface soil were determined as $28.40-77.68 \%, 7.60-46.88 \%$ and $14.72-34.72 \%$, respectively, whereas sand, clay, and silty content of subsurface soil were found as $41.12-81.12 \%, 6.88-40.88 \%$ and $12-34 \%$ in study area. In addition, dominant texture of the surface and subsurface study area soils were determined as sandy loam. $\mathrm{pH}$ values of surface soil were between 3.76 and 5.63 while, subsurface soils were between 3.70 and 6.62 . Organic matter content of the surface soils were between $0.61 \%$ and $3.01 \%$, while subsurface soils were between $0.48 \%$ and $4.24 \%$. Although nitrogen, phosphorus and potassium contents, which are called macro nutrients of soils, are generally inadequate, there is no problem in the micronutrients, copper and iron, while zinc and manganese contents are found inadequate.
\end{abstract}

Keywords: Tea plant, soil properties, Çataklı Basin 


\section{Giriş}

Çay (Camellia sinensis $\quad$ L.), işlenmiş bitki yapraklarının kaynatılmasıyla veya haşlanmasıyla elde edilen bir içecektürüdür. Dünyada sudan sonra en fazla tüketilen içecek hiç şüphesiz ki çaydır (Kacar, 2010). Çay bitkisi Kuzey yarım kürede $42^{\circ}$, Güney yarım kürede $27^{\circ}$ boylamı arasında gelişim göstermektedir (Özyazıcı ve ark., 2010). Büyük çay üreten ülkelerdeki çay üretiminde artış olması nedeniyle dünya üretiminde de büyüme gözlemlenmiştir. Uzak doğu, 2013 yılı verilerine göre çay üretiminde 3.9 milyon ton ile en büyük kısmı oluşturmakta ve bu ülkeler içinde de Çin 1.9 milyon ton ile baş1 çekmektedir. Afrika ülkelerinde üretim 0.6 milyon ton, yakın doğuda ise 0.26 milyon ton olarak tespit edilmiştir. Türkiye'deki çay üretimi ise yine 2013 verilerine göre 0.23 milyon ton olarak kaydedilmiştir. Türkiye dünyada çay üretimi açisından önde gelen bir ülkedir. Üretim alanlarının büyüklüğüne göre dünyada altıncı, çay üretim miktarı açısından beşinci sıradadır (Adiloğlu ve Adiloğlu, 2006). Türkiye'de çay, sadece Gürcistan sınırından başlayan ve Fatsa'ya kadar uzanan alan içerisinde yetiştirilebilmektedir (Kacar, 2010).

Çay bitkisinin yetişmesine etki yapan en önemli etkenler iklim ve toprak özellikleridir. Çay sıcak ve yağışlı iklimsel şartlar altındaki bazı bölgelerde gelişebilmektedir (Özyazıcı ve ark., 2010). Asgari yıllık $1250 \mathrm{~mm}$ yağ arasında değişen sıcaklık, 2000 metreye kadar olan ve 0.5-10 derecelik eğime sahip yamaç alanlar çay bitkisi için ideal alanlardır. Bu nedenle dünyadaki çay üretimi birkaç alanla sınırlıdır ve yetiştirme alanının şartlarındaki değişime son derece duyarlıdır. Sınırlı olan bu çay üretim alanlarının koşulları iklim değişikliği sonucu risk altındadır (Anonymous, 2015).

Yillık sicaklık ortalamasının $14{ }^{\circ} C^{\prime}$ nin altına düşmemesi, toplam yıllık yağışin 2000 mm'den az olmaması ve aylara göre dağılımının düzenli olmas1, bağıl nem oranının ise en az \% 70 olmas1, çay bitkisinin normal gelişimi için gerekli olan iklim koşullarıdır. Toprak özellikleri yönünden asit reaksiyonlu toprakları seven çay bitkisi, genelde 4.5-6 arasında değişen pH'ya sahip ve aktif kireç miktarı düşük topraklarda optimum gelişme gösterir (Sharma ve Ranhanathan, 1985). Toprak pH'sinin asit ya da alkalin yöndeki değişimlerinden olumsuz yönde etkilenirken, toprak pH's1 4'ün altına düştüğünde istenen verim ve kalitede ürün alınamaz hale gelir (Eden, 1976; Tekeli, 1976; Kacar, 1984). Toprak tekstürü açısından kumdan killi tekstüre kadar değişen topraklarda yetişebilen çay bitkisi, toprağın derin ve bitki besin maddelerince zengin olmasin1 isterken; ağır killi, kireçli ve taban suyu yüksek alanlarda ise bitki gelişimi olumsuz yönde etkilenmeye başlar. $\mathrm{Bu}$ nedenle çay yetiştiriciliği yapılan düz arazilerin organik maddece zengin ve geçirgenliğinin yüksek olması istenirken, eğimli arazilerde de eğimin \% 50'den fazla olmaması ve eğimin etkilerini azaltmak için de setleme ile teraslama yapılması tavsiye edilir (Özyazıcı ve ark., 2014).

Doğu Karadeniz Bölgesi'nin sarp ve engin dağlarla çevrili olması, mekanizasyonun kullanılamaması sebebiyle, tarım ve hayvancılığın istenilen düzeyde gelişememesine neden olmaktadır. Bu sebeple bölgeye oldukça uyum sağlayan çay bitkisi, bölge ekonomisi açıdan büyük bir öneme sahiptir.

$\mathrm{Bu}$ çalışmanın amacı, Trabzon ili Of ilçesi sınırları içerisinde yer alan Çataklı Havzası'nın doğu kesimine ait farklı topografik pozisyon, bakı ve yükseltiler üzerinde dağ 1 lım gösteren toprakların çay tarımı açısından fiziksel, kimyasal ve verimlilik özelliklerini incelemek, belirlenen sorunlara karşı çözüm önerileri getirmektir.

\section{Materyal ve Yöntem}

\section{1. Çalışma alanının genel özellikleri}

Çalışma alanı Trabzon ili Of ilçesi sınırları içerisindedir. Çalışma alanı Çataklı Çayı aşağı havzası su bölümü çizgileri dikkate alınarak sınırlandırılmıştır. Havza yaklaşık $53 \mathrm{~km}^{2}$ alana sahip olup, 604000-61100 doğu ve 45240004532000 kuzey (UTM, m) koordinatları arasında yer almaktadır (Şekil 1).

Çalışma alanında; her mevsim yağışli, yıllık sıcaklık farkının çok olmadığı tipik Karadeniz iklimi görülür. Trabzon meteoroloji istasyonu verilerine göre, uzun y1llar (1950-2015) yıllık ortalama yağış $813.2 \mathrm{~mm}$ 'dir. Uzun yıllık ortalama sicaklik ise $14.8{ }^{\circ} \mathrm{C}$ 'dir (Anonim, 2016). Trabzon meteoroloji istasyonu verileri Thornthwaite formülüne uygulanmış ve su bilançosu tablosu oluşturulmuştur (Tablo 1). Tablodaki veriler kullanılarak iklim diyagramı çizilmiştir (Şekil 2). $\mathrm{Bu}$ diyagramdan görüleceği üzere buharlaşma eğrisi Nisan ortalarından Eylül ortalarına kadar yağış eğrisinin üzerinde seyretmektedir. Nisan sonu, Mayss ve Haziran aylarında toprakta birikmiş su kullanıldığından bu aylarda kuraklık etkili değildir. Buna karşı1ık Temmuzda etkili olmaya başlayan kuraklık, Eylül ortalarına kadar devam etmektedir. Bu süre yaklaşık iki buçuk ayı bulmaktadir.

Thorthwaite metoduna göre Trabzon $\mathrm{C}_{2}$ harfi ile gösterilen yarı nemli iklim tipine dâhil olmaktadır. Ayrıca b'2s b'4 harfleri ile ifade edilen 


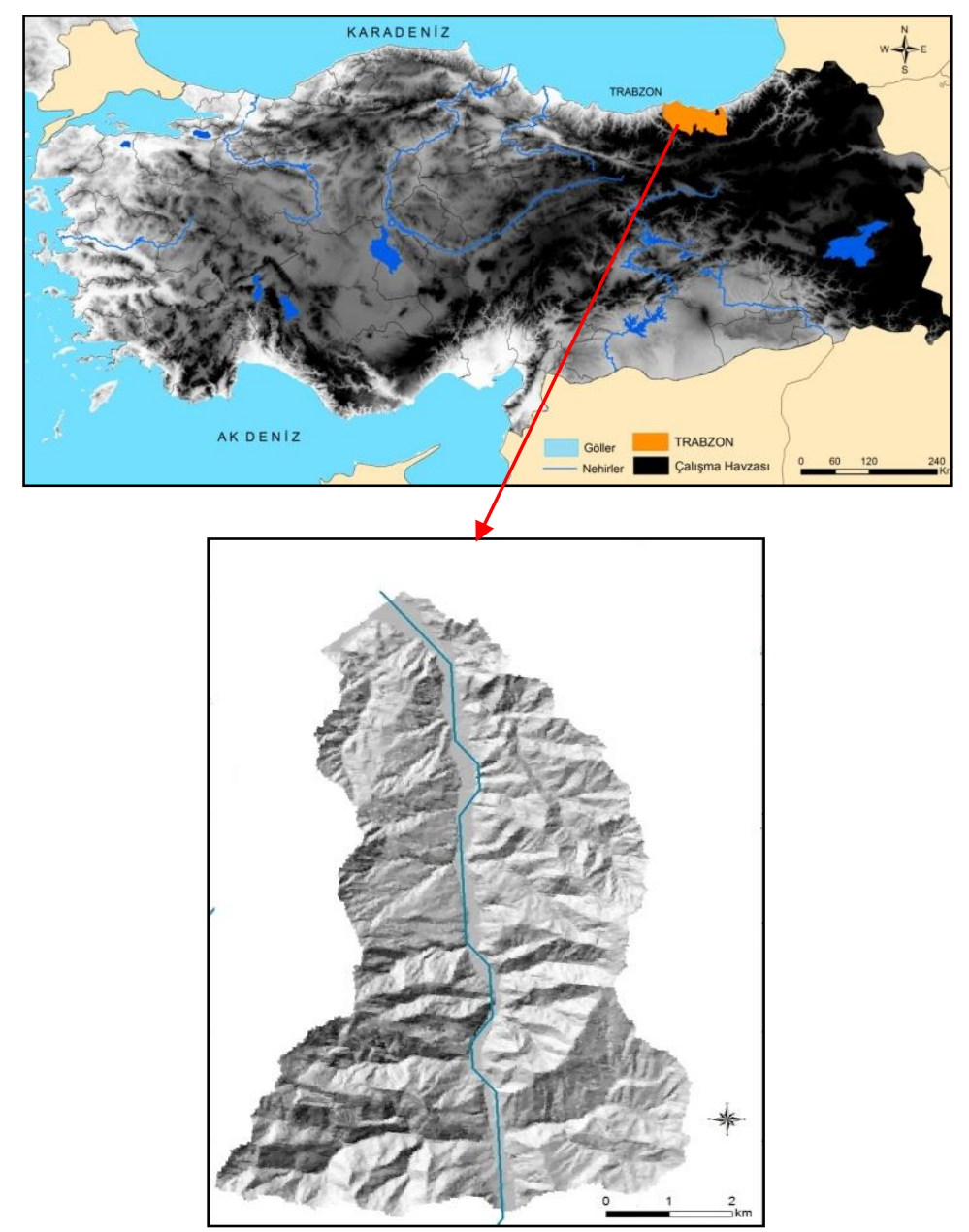

Şekil 1. Çalışma alanının lokasyon haritası

Tablo 1. Thorthwaite'e göre çalışma alanının su bilançosu(1950-2015)

\begin{tabular}{|c|c|c|c|c|c|c|c|c|c|c|c|c|c|}
\hline & & & & & & & ylar & & & & & & \\
\hline & 1 & 2 & 3 & 4 & 5 & 6 & 7 & 8 & 9 & 10 & 11 & 12 & $Y$ \\
\hline $\mathrm{T}$ & 7.5 & 7.4 & 8.5 & 11.9 & 16.0 & 20.4 & 23.2 & 23.5 & 20.4 & 16.5 & 12.7 & 9.6 & 14.8 \\
\hline Sİ & 1.8 & 1.8 & 2.2 & 3.7 & 5.8 & 8.4 & 10.2 & 10.4 & 8.4 & 6.1 & 4.1 & 2.7 & 65.7 \\
\hline DmPE & 19.6 & 19.2 & 23.7 & 39.7 & 62.4 & 90.4 & 110.1 & 112.3 & 90.4 & 65.4 & 43.8 & 28.6 & \\
\hline DüPE & 16.3 & 15.9 & 24.4 & 44.1 & 77.7 & 114.0 & 139.9 & 133.3 & 93.8 & 62.5 & 36.1 & 22.8 & 780.9 \\
\hline $\mathrm{P}$ & 79.0 & 61.0 & 58.5 & 57.2 & 52.7 & 50.7 & 34.4 & 45.5 & 78.1 & 116.4 & 96.1 & 80.6 & 810.2 \\
\hline AD. & - & - & - & - & -25.0 & -63.3 & -11.7 & - & - & 53.9 & 46.1 & - & \\
\hline W & 100.0 & 100.0 & 100.0 & 100.0 & 75.0 & 11.7 & - & - & - & 53.9 & 100.0 & 100.0 & \\
\hline U & 16.3 & 15.9 & 24.4 & 44.1 & 77.7 & 114.0 & 46.1 & 45.5 & 78.1 & 62.5 & 36.1 & 22.8 & 583.6 \\
\hline D & - & - & - & - & - & - & 93.8 & 87.8 & 15.7 & - & - & - & 197.3 \\
\hline $\mathrm{R}$ & 62.7 & 45.1 & 34.1 & 13.1 & - & - & - & - & - & - & 13.9 & 57.8 & 226.6 \\
\hline S & 60.2 & 53.9 & 39.6 & 23.6 & 6.6 & - & - & - & - & - & 6.9 & 35.8 & 226.6 \\
\hline $\mathrm{NO}$ & 3.8 & 2.8 & 1.4 & 0.3 & -0.3 & -0.6 & -0.8 & -0.7 & -0.2 & 0.9 & 1.7 & 2.5 & \\
\hline
\end{tabular}

T: Sıcaklık $\left({ }^{\circ} \mathrm{C}\right)$, SI: Sıcaklık indisi, DmPE: Düzeltilmemiş Evapotransprasyon, DüPE: Düzeltilmiş Evapotransprasyon, P: Yağış (mm), D: Su noksanlığ 1 , S: Su fazlalığ 1 , R: İlave su, U: Kullanılan su, Y: Yıllık, NO: Nemlilik oranı, AD: Aylık değişim, W: $100 \mathrm{cmderin} \mathrm{lik} \mathrm{içerindeki} \mathrm{mak} \mathrm{si} \mathrm{mu} \mathrm{m}$ $\mathrm{su}$

orta sıcaklıkta, su noksanı yaz mevsiminde ve orta derecede olan okyanus iklimine yakın iklim tipi olarak s rralanabilir.

Havza yükseltisi 0 ile $980 \mathrm{~m}$ arasında olup, yaklaşık \% $73.8^{\prime}$ 'i $350-450 \quad \mathrm{~m}$ yükseklik arasındadır. Havzanın eğim değerleri havza tabanında $\% \quad 0-5$ arasında iken, çevresindeki yüksek sahalarda ise $\% \quad 50$ eğimin üzerine çıkmaktadır. Havza çoğunlukla batı-güneybatı ile kuzey-kuzeydoğu bakıları arasında yer almaktadır (Şekil 3). 


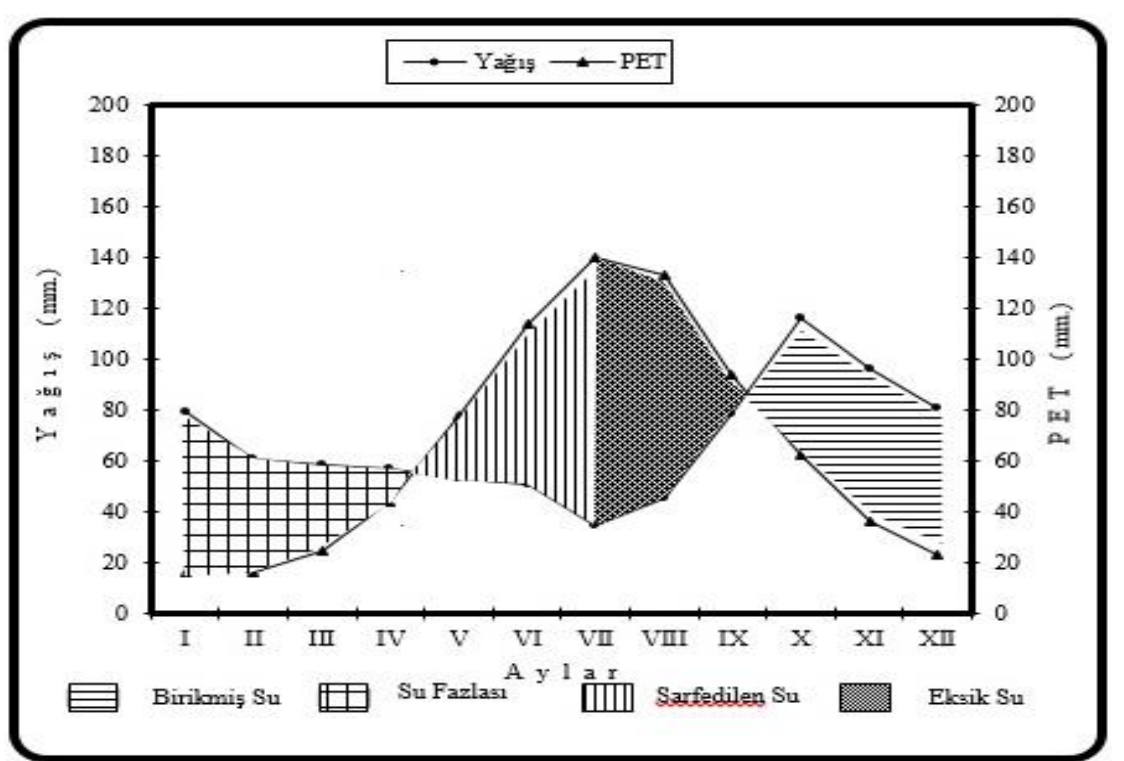

Şekil 2. Çalışma alanı topraklarının su bilançosu diyagramı(1950-2015)
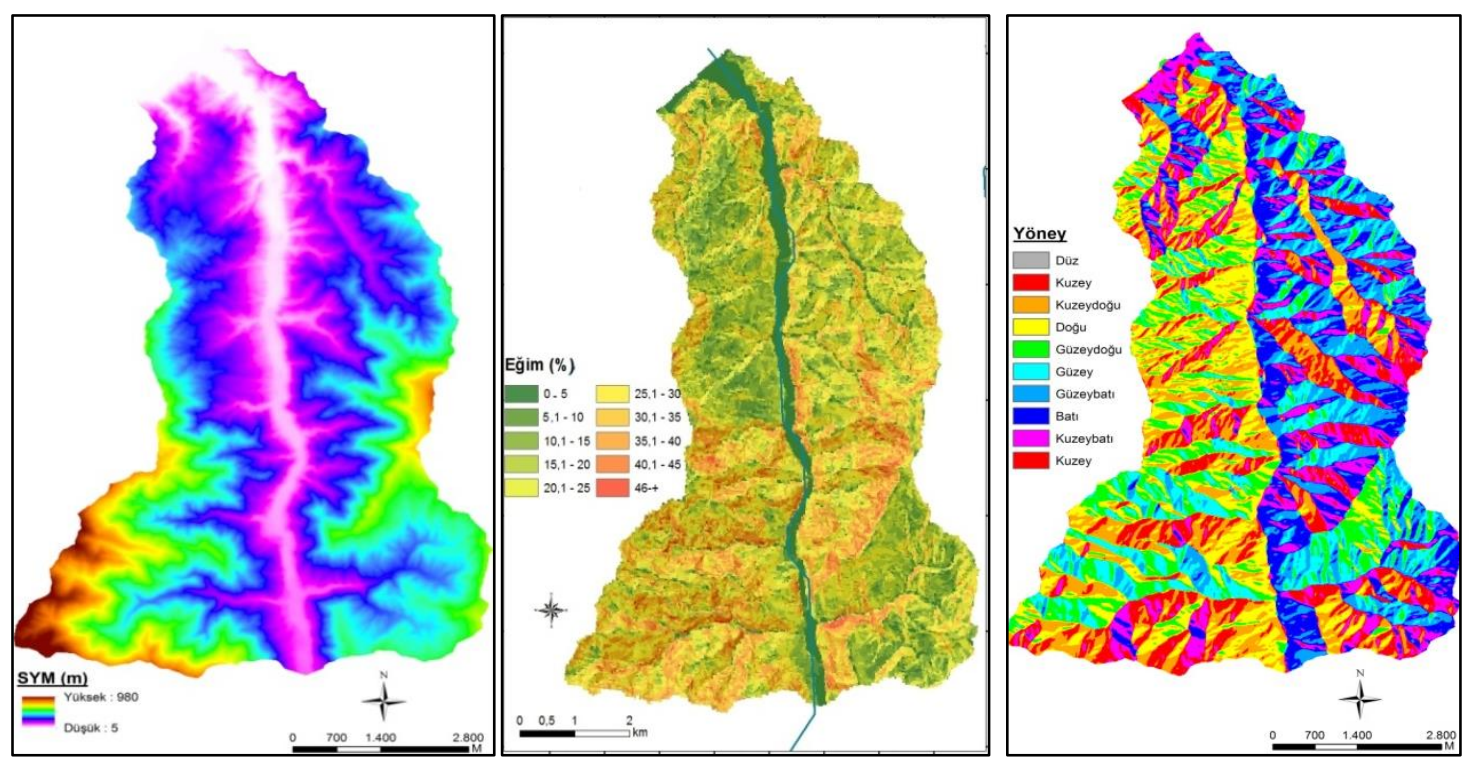

Şekil 3. Çalışma alanının sayıs al yüks elti, eğimve bakı haritaları

Çalışma alanında jeolojik olarak 4 birim bulunmakta (Şekil 4), akarsu çevresinde kuvaterner yaşlı alüvyon araziler yer almaktadır. $\mathrm{Bu}$ araziler üzerinde özellikle 5,7 ve 8 no'lu örnekler yer alırken, etek araziler ile alt yamaç araziler özellikle koluviyal birikintiler üzerinde yer almaktadır. En fazla yayılış gösteren Üst Kretase yaşı volkanik arazilerdir. Bunun dışında çalışma alanının kuzeybatısında dar alanlı Üst Kretase yaşı 1 dasit, riyolit içeren birim yer alırken, çalışma alanının güneydoğusunda ise Üst-Kretase-Eosen yaşlı kırıntılılar ve karbonatlar yayılış göstermektedir.

\section{2. Çalışma alanından toprak örneklerinin} alınması ve analiz yöntemleri

Toprak örnekleri Çataklı Çayı Havzası'nın doğu yakasında yer alan ve çay tarımı yapılan alanlardan yüzey $(0-30 \mathrm{~cm})$ ve yüzey altı $(30-60$ $\mathrm{cm})$ olmak üzere 16 noktadan toplam 32 örnek alınmıştır. Toprak örneklerinin alınmasında; alanın farklı yükselti, bakı, eğim, taban, etek arazi, alt yamaç, üst yamaç, omuz ve tepe üstü düzlük olmak üzere altı farklı fizyografik birim göz önünde bulundurulmuştur (Tablo 2). Alınan bu örneklerin analizleri yapılmak üzere laboratuvara getirilmiş, laboratuvara getirilen örnekler 


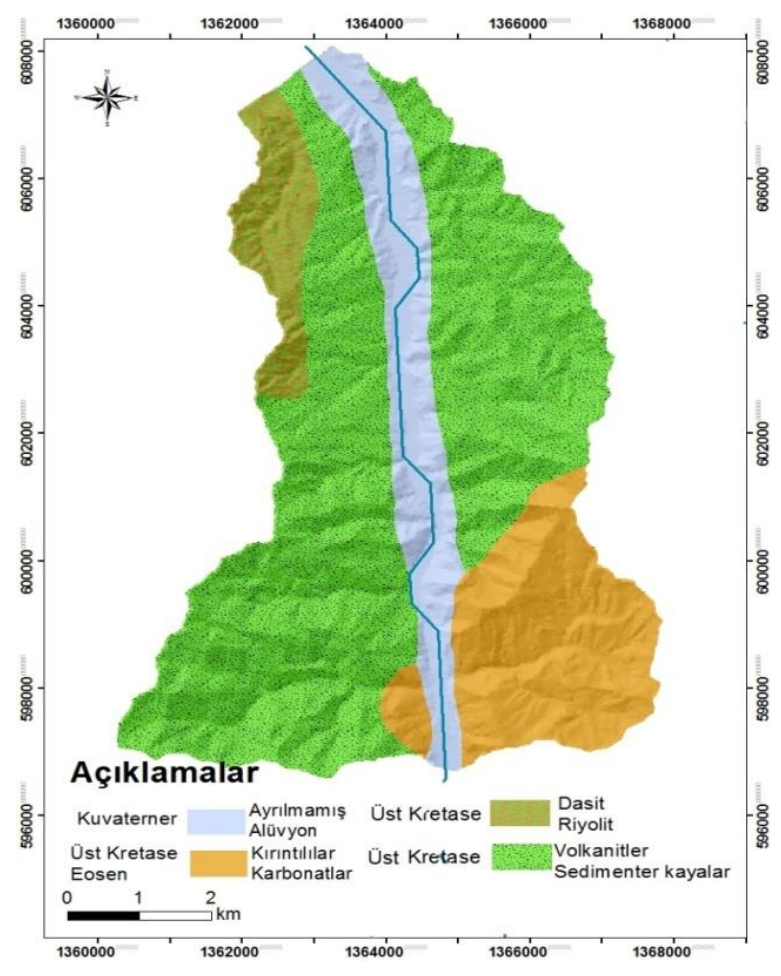

Şekil 4. Çalışma alanı jeoloji haritası

Tablo 2. Çataklı Çayı Havzası'nın doğu yakasında, çay tarımı yapılan alanlardan alına toprak örneklerinin konumsalözellikleri

\begin{tabular}{clllclc}
\hline Örnek no & Koordinat (UTM, m) & Bak1 & Yükseklik (m) & Arazi şekli & Eğim (\%) \\
\hline 1 & 609277 & 4529005 & Kuzeydoğu & 226 & Ust yamaç & $45-50$ \\
2 & 609327 & 4529000 & Kuzeydoğu & 195 & Alt yamaç & $25-30$ \\
3 & 609293 & 4529034 & Kuzeydoğu & 195 & Alt yamaç & $45-50$ \\
4 & 609272 & 4529069 & Kuzeydoğu & 196 & Alt yamaç & $40-50$ \\
5 & 609368 & 4529033 & Kuzeydoğu & 175 & Taban & $0-10$ \\
6 & 609352 & 4529028 & Kuzeydoğu & 185 & Etek-Yamaç-Alt Yamaç geçiş & $40-50$ \\
7 & 609337 & 4529066 & Kuzey & 176 & Etek & $10-15$ \\
8 & 609298 & 4529119 & Kuzeydoğu & 174 & Taban & $0-10$ \\
9 & 609299 & 4528951 & Kuzey & 225 & Üst yamaç & $30-35$ \\
10 & 609345 & 4528900 & Kuzey & 221 & Üst yamaç & $35-40$ \\
11 & 609376 & 4528455 & Kuzey & 353 & Sirt & $15-20$ \\
12 & 609301 & 4528516 & Kuzey & 346 & Sirt & $30-35$ \\
13 & 609219 & 4528574 & Kuzey & 349 & Sirt & $30-35$ \\
14 & 609538 & 4528225 & Güneydoğu & 430 & Omuz & $30-35$ \\
15 & 609413 & 4528431 & Kuzeybatı & 420 & Tepe üstü düzlük & $0-10$ \\
16 & 609239 & 4528431 & Güneydoğu & 395 & Omuz & $20-25$ \\
\hline
\end{tabular}

kurutularak $2 \mathrm{~mm}$ elekten elenmiş ve analize hazırlanmıștır.

Çalışma kapsamında alandan alınan toprak örneklerinde; Bouyoucos hidrometre yöntemiyle bünye (Bouyoucos, 1951), Scheibler kalsimetresi ile volümetrik olarak kireç (Nelson, 1982); organik madde, Modifiye Walkley-Black yaş yakma yöntemiyle (Nelson ve Sommers, 1982) belirlenmiştir. Alınan toprak örneklerinde; 1:2.5'lik toprak-su karışımında pH (Richards, 1954) ve elektriksel iletkenlik (EC) (Rhoades,
1986); alkalin ve nötr karakterli toprakların alınabilir fosfor (P) içerikleri, Olsen yöntemine göre (Olsen ve ark., 1954); asit karakterli toprakların P içerikleri ise, Bray ve Kurtz (1945) yöntemine göre; ekstrakte edilebilir potasyum (K), kalsiyum $(\mathrm{Ca})$, magnezyum $(\mathrm{Mg})$ ve sodyum $(\mathrm{Na})$ (Anonymous, 1992), DTPA ile ekstraksiyon sonrasinda elde edilen çözeltinin atomik adsorbsiyon spektrofotometresinde okunmasiyla alınabilir demir $(\mathrm{Fe})$, bakır $(\mathrm{Cu})$, çinko $(\mathrm{Zn})$ ve mangan (Mn) (Anonymous, 1990a) belirlenmiştir. 


\section{Bulgular ve Tartışma}

Doğu Karadeniz Bölgesi'nde yer alan Trabzon ili Of ilçesi sınırları içerisinde bulunan Çataklı Çayı Havzası'nın doğu yakasında çay tarımı yapılan alanlarından alınan yüzey $(0-30 \mathrm{~cm})$ ve yüzey altı
$(30-60 \mathrm{~cm})$ toprak örneklerinin bazı fiziksel, kimyasal ve verimlilik analiz sonuçlarına ait tanımlayıc1 istatistikler Tablo 3 ve Tablo 4'te, incelenen toprak özelliklerinin fiziksel ve kimyasal, makro ve mikro besin element analiz sonuçları ise Tablo 5 ve 6'da sunulmuştur.

Tablo 3. Yüzey $(0-30 \mathrm{~cm})$ ve yüzey altı $(30-60 \mathrm{~cm})$ topraklarının fiziksel ve kimyasal özelliklerine ait tanımlayıcı is tatis tikleri $(\mathrm{n}=16)$

\begin{tabular}{|c|c|c|c|c|c|c|c|}
\hline & $\%$ kil & $\%$ Silt & $\%$ Kum & $\% \mathrm{OM}$ & $\mathrm{pH}$ & $\mathrm{EC}$ & $\%$ Kireç \\
\hline \multicolumn{8}{|c|}{ Yüzey $(0-30 \mathrm{~cm})$} \\
\hline Ortalama & 16.76 & 23.50 & 59.73 & 1.71 & 4.60 & 0.24 & 0.54 \\
\hline Standart sapma & 9.19 & 5.60 & 12.69 & 0.77 & 0.52 & 0.16 & 0.58 \\
\hline Değişkenlik katsayısı ${ }^{*}$ & 39.28 & 20.00 & 49.28 & 2.40 & 1.87 & 0.52 & 1.96 \\
\hline Vary ans & 84.57 & 31.37 & 161.09 & 0.603 & 0.274 & 0.028 & 0.33 \\
\hline En düşük & 7.60 & 14.72 & 28.40 & 0.61 & 3.76 & 0.04 & 0.01 \\
\hline En yüksek & 46.88 & 34.72 & 77.68 & 3.01 & 5.63 & 0.56 & 1.97 \\
\hline Carp $1 k l 1 k^{* *}$ & 2.49 & 0.03 & -0.86 & 0.36 & 0.24 & 0.77 & 1.28 \\
\hline Basiklik & 7.99 & -0.34 & 1.07 & -1.14 & -0.16 & -0.75 & 1.06 \\
\hline \multicolumn{8}{|c|}{ Yüzey alt1 $(30-60 \mathrm{~cm})$} \\
\hline Ortalama & 18.57 & 22.82 & 58.60 & 1.63 & 5.22 & 0.17 & 1.08 \\
\hline Standart sapma & 8.38 & 5.59 & 11.87 & 1.02 & 0.76 & 0.11 & 0.58 \\
\hline Değişkenlik katsayısı ${ }^{*}$ & 34.00 & 22.00 & 40.00 & 3.76 & 2.62 & 0.35 & 1.96 \\
\hline Varyans & 70.33 & 31.31 & 140.1 & 1.05 & 0.586 & 0.01 & 0.34 \\
\hline En düşük & 6.88 & 12.00 & 41.12 & 0.48 & 3.70 & 0.05 & 0.01 \\
\hline En yüksek & 40.88 & 34.00 & 81.12 & 4.24 & 6.32 & 0.40 & 1.97 \\
\hline Çarp $1 \mathrm{kl}^{* \mathrm{k}^{* *}}$ & 1.057 & -0.06 & 0.35 & 1.48 & -0.46 & 0.59 & -0.58 \\
\hline Basıklık & 2.206 & -0.03 & -0.61 & 1.70 & -0.31 & -1.03 & -0.37 \\
\hline
\end{tabular}

OM: Organik madde, *: Değişkenlik Katsayısı: $<15$ = Düşük Değişkenlik, 15-35 = Orta Değişkenlik, >35 = Yüksek Değişkenlik

${ }^{* *}:$ Çarpıklık: $<|\mp 0.5|=$ Normal Dağılım, $0.5-1.0=$ Veri setine karakter dönüşümü uygulanır, Çarpıklık $>1.0 \rightarrow$ Logaritma dönüşümü uygulanır

Tablo 4. Yüzey $(0-30 \mathrm{~cm})$ ve yüzey altı $(30-60 \mathrm{~cm})$ topraklarının verimlilik özelliklerine ait tanımlayıcı is tatistikleri $(\mathrm{n}=16)$

\begin{tabular}{|c|c|c|c|c|c|c|c|c|c|c|c|}
\hline & $\mathrm{Na}$ & $\mathrm{K}$ & $\mathrm{Ca}$ & $\mathrm{Mg}$ & $\mathrm{N}$ & $\bar{P}$ & $\overline{\mathrm{K}}$ & $\mathrm{Cu}$ & $\mathrm{Zn}$ & $\mathrm{Fe}$ & $\mathrm{Mn}$ \\
\hline & & $(\mathrm{cm}$ & $\left(\mathrm{kg}^{-1}\right)$ & & $\left(\mathrm{kg} \mathrm{da}^{-1}\right.$ & $\left.\mathrm{P}_{2} \mathrm{O}_{5} \mathrm{da}^{-1}\right)$ & $\left(\mathrm{kg} \mathrm{K}_{2} \mathrm{O} \mathrm{da}^{-1}\right)$ & \multicolumn{4}{|c|}{$\left(\mathrm{mg} \mathrm{kg}^{-1}\right)$} \\
\hline \multicolumn{12}{|c|}{ Yüzey $(0-30 \mathrm{~cm})$} \\
\hline Ortalama & 0.34 & 0.33 & 10.54 & 4.18 & 1.97 & 11.59 & 5.68 & 1.04 & 0.47 & 94.36 & 3.38 \\
\hline StdS & 0.56 & 0.28 & 4.87 & 1.92 & 0.89 & 9.38 & 4.85 & 0.57 & 0.28 & 27.19 & 4.69 \\
\hline DK & 0.19 & 0.94 & 17.64 & 6.02 & 2.75 & 37.97 & 16.31 & 1.80 & 0.47 & 105.73 & 16.57 \\
\hline Varyans & 0.003 & 0.07 & 23.74 & 3.68 & 0.79 & 87.99 & 23.54 & 0.33 & 0.08 & 739.51 & 22.01 \\
\hline En düşük & 0.25 & 0.05 & 0.78 & 0.59 & 0.71 & 1.71 & 0.89 & 0.52 & 0.15 & 27.40 & 0.79 \\
\hline En yüksek & 0.44 & 0.99 & 18.42 & 6.61 & 3.46 & 39.68 & 17.20 & 2.32 & 1.21 & 133.13 & 17.36 \\
\hline Çarp $1 k l ı k^{* *}$ & 0.206 & 1.03 & -0.30 & -0.44 & 0.36 & 1.81 & 1.08 & 1.10 & 1.15 & -0.98 & 2.56 \\
\hline Basıklik & 0.77 & 0.33 & -0.26 & -1.14 & -1.15 & 4.73 & 0.50 & -0.54 & 1.97 & 1.15 & 5.79 \\
\hline \multicolumn{12}{|c|}{ Yüzey alt1 $(30-60 \mathrm{~cm})$} \\
\hline Ortalama & 0.36 & 0.23 & 13.27 & 6.31 & 1.87 & 6.00 & 4.11 & 0.65 & 0.45 & 75.13 & 1.98 \\
\hline StdS & 0.04 & 0.19 & 5.69 & 2.85 & 1.18 & 4.11 & 3.53 & 0.80 & 0.19 & 32.51 & 0.47 \\
\hline DK & 0.15 & 0.75 & 19.43 & 10.75 & 4.32 & 12.34 & 13.47 & 3.06 & 0.75 & 112.75 & 1.96 \\
\hline Varyans & 0.002 & 0.04 & 32.45 & 8.17 & 1.39 & 16.94 & 12.46 & 0.64 & 0.03 & 1057.01 & 0.22 \\
\hline En düşük & 0.28 & 0.06 & 0.73 & 0.98 & 0.55 & 0.95 & 1.00 & 0.46 & 0.19 & 10.39 & 1.08 \\
\hline En yüksek & 0.43 & 0.81 & 20.16 & 11.73 & 4.87 & 13.29 & 14.47 & 3.52 & 0.94 & 123.14 & 3.04 \\
\hline Çarp $1 \mathrm{kl} \mathrm{k}^{* *}$ & -0.02 & 1.77 & -1.29 & 0.316 & 1.48 & 0.63 & 1.86 & 0.61 & 0.83 & -0.42 & 0.20 \\
\hline Basıklık & -1.02 & 3.66 & 1.30 & -1.02 & 1.69 & -0.82 & 4.14 & 0.56 & 1.22 & -0.48 & 0.63 \\
\hline
\end{tabular}

StdS: Standart sapma, DK: Değişkenlik katsayısı, *Değişkenlik Katsayısı: $<15=$ Düşük Değişkenlik, $15-35=$ Orta Değişkenlik, >35=Yüksek Değişkenlik **Çarpıklık:< $|\mp 0,5|=$ Normal Dağılım, $0,5-1,0=$ Veri setine karakter dönüşümü uygulanır. ÇK $>1,0 \rightarrow$ Logaritma dönüşümü uygulanır.

Tablo 3'te verilen tanımlayıcı is tatistik verileri değerlendirildiğinde; çarpıklık katsayıları yüzey örneklerinde $(0-30 \mathrm{~cm})$ kil ve kireç için normal dağılımdan uzak pozitif çarpıklık gösterdiği ve kumun incelenen tüm örnekler içinde tek negatif çarpıklığa sahip olan özellik olduğu görülmektedir. Yüzey altı örneklerine ait $(30-60 \mathrm{~cm})$ bazı fiziksel ve kimyasal analiz sonuçlarına göre ise; çarpıklık 
katsayıları kil ve organik madde için normal dağılımdan uzak pozitif çarpıklık; silt, pH ve kireç için ise negatif bir çarpıklık göstermektedirler.

Tablo 4'de verimlilik kriterleri bakımından yüzey ve yüzey altı toprak örneklerinin tanımsal istatistik değerleri incelendiğinde; $\mathrm{K}, \mathrm{P}, \mathrm{K}, \mathrm{Cu}, \mathrm{Zn}$ ve $\mathrm{Mn}$ normal dağılımdan uzak pozitif dağılım gösterip; $\mathrm{Ca}, \mathrm{Mg}$ ve $\mathrm{Fe}$ ise negatif bir çarpıklık göstermektedir. Pozitif çarpıklık katsayıları, incelenen fiziko-kimyasal toprak özelliklerinin ortalamanın üzerinde aşırı uç değerlere sahip olduğunu açıklarken, negatif çarpıklık katsayısı gösteren özelliklerin ise bazı alanlarda ortalamanın aşırı altında değerler aldığını ortaya koymaktadır. Toprak özelliklerinde ortaya çıkan bu farklı değerlerin varlığ 1 , toprak özelliklerine ait değişkenlik katsayılarının da farklı olmasını desteklemektedir. Wilding (1985) ve Mulla ve Mc Bratney (2000) toprak özelliklerindeki değişimlerin açıklanmasında önemli bir gösterge olarak kabul edilen değişkenlik katsayısını, aldığ1 değerlere göre düşük ( $<\%$ 15), orta $(\%$ 15-35) ve yüksek (> \% 35) olarak sinıflandırmaktadırlar. Yapılan bu çalışmada; çalışma alanının fiziksel ve kimyasal özelliklerine ait değişkenlik sayıları yüzey ve yüzey altı toprak örnekleri için her ikisinde de kum (\% 49.28 ve \% 40.00) yüksek değişkenliğe sahipken, kil ise yüzey örneğinde (\% 39.28) yüksek ve yüzey alt1 örneğinde (\% 34.00) ise orta değişkenliğe sahip olarak belirlenmiştir. Silt değeri ise yüzey ve yüzey altı her iki durumda da orta değişkenliğe sahiptir. Ayrıca diğer parametrelerin düşük değişkenlik gösterdiği tespit edilmiştir. $\mathrm{Bu}$ durum verimlilik parametreleri için değerlendirildiğinde (Tablo 4) ise yüzeyde en çok değişkenliğe sahip olan verimlilik parametresinin Fe (105.73) olduğu; Ca, $\mathrm{K}$ ve $\mathrm{Mn}$ orta değişkenlik, diğer geri kalan parametrelerin ise düşük değişkenlik gösterdiği tespit edilmiştir. Yüzey altında ise durum en yüksek değişkenlik Fe (112.01), orta değişkenlik Ca (19.43) ve diğer tüm parametreler için düşük değişkenlik katsayısı ile ifade edilmiştir.

Toprağın kum, kil ve silt gibi parçacıkların oranından oluşan toprak bünyesi, toprağın verimlilik düzeyini belirleyen önemli fiziksel özelliklerinden olup, gübreleme yönünden büyük önem taşımaktadır. Araştırmada, 0-30 cm toprak derinliğinde kum, kil ve silt içerikleri sırasıyla \% 28.4-77.6, \% 7.6-46.8 ve \% 14.7-34.7 arasinda; yüzey altı $(30-60 \mathrm{~cm})$ derinlikte ise \% 41.1-81.1, \% 6.8-40.8 ve \% 12.0-34.0 arasında değiştiği belirlenmiştir. Toprak örnekleri; kil (C), tın (L), kumlu tın (SL), tınlı (LS), kum (S), kumlu killi tın (SCL) olmak üzere 6 farklı bünye sinıfinda tespit edilmiş olup, toprakların büyük çoğunluğunu kaba (SL) bünyeye sahip topraklar oluşturmaktadır
(Tablo 5). Eğimin en düşük olduğu alanlarda kil oranı \% 46.8 iken, eğimin en yüksek olduğu (\% 45-50) alanlarda ise kum değeri \% 77.6'dır. Bu durum özellikle eğimin fazla olduğu yamaç arazilerden kil gibi ince materyalleri eğimin az olduğu alanlara taşınıp birikmesinden kaynaklandığı düşünülmektedir. Özyazıcı ve ark. (2011) Artvin ili içerisinde yer alan çay tarımı yapılan topraklardan aldıkları 220 adet örnekte yaptıkları çalışmalarında; toprakların kum içeriklerinin \% $\quad 16-28$ ile \% 76.84 arasında, kil içeriğinin ise \% 6.05 ile $\% \quad 54.86$ arasında olduğunu belirlemişlerdir. Müftüoğlu ve ark. (2010) Trabzon-Of ilçesinde çay tarımı yapılan topraklardan aldıkları 12 örnekte 6 örneğin kumlu kil tın, 5 adedinin kumlu tın ve bir tanesinin de tınlı bünyeye sahip olduğunu tes pit etmiş lerdir.

Çalışma alanı topraklarının pH'ları 3.7-5.6 arasında değișiklik göstermektedir (Tablo 5). İncelenen toprak örneklerinin analiz sonuçlarının Ülgen ve Yurtsever (1995) tarafindan bildirilen sınır değerlerine göre sinıflandırıldı̆̆ında; $\mathrm{pH}$ değerleri yüzeyde ve derinde her iki durumda da kuvvetli asit, orta ve hafif asit değerleri arasında değiştiği belirlenmiştir. Birçok araştırmacının belirttiğine göre (Eden, 1976; Tekeli, 1976; Kacar, 1984), çay tarımı için optimum $\mathrm{pH}$ aralığ1 4.5-6.0 arasında değişiklik göstermektedir. Toprakların kuvvetli asit düzeylerine gelmelerinde en önemli etken yağışın ve toprak bünyesinin kum fraksiyonunun yüksek olmasindan dolayı bazik katyonların yıkanarak ortamdan uzaklaşmasıdır. Çalışma alanı çay topraklarının pH'sının bu değişim aralığıyla ilgili bulgular, daha önce Karadeniz Bölgesi'nin diğer alanlarında yapılan araștırma bulguları (Özuygur ve ark., 1974; Müftüoğlu, 1990; Özyazıcı ve ark., 2010 ve 2013) ile büyük ölçüde benzerlik göstermektedir. Çay tarıminda optimum verim alınabilmesi amaciyla bitkilerin gerek toprakta bulunan, gerekse de gübreleme ile ortama verilen besin elementlerinden en iyi şekilde faydalanabilmesi ancak toprakların uygun $\mathrm{pH}$ değerlerine getirilmesi ile mümkündür. Bu amaçla özellikle $\mathrm{pH}$ değeri 4.5 altında olan alanlara kireçli materyallerin uygulanması gerekir.

Araștırma alanındaki toprak örneklerinin kireç içeriklerinin oldukça düşük olup yüzeyde ve derinde $\% \quad 0.01$ ile $\% \quad 1.97$ arasında değiştiği belirlenmiştir (Tablo 5). Özyazıcı ve ark. (2016) Orta ve Doğu Karadeniz Bölgesi'nde yer alan sekiz ile ait tarım topraklarından alınan 3400 toprak örneğinde yaptıkları çalışmada; yüzey topraklarının kireç içeriğinin \% $\quad 0.1$ ile 58.8 arasında değiştiğini ve kireçlilik yönünden $0-30$ $\mathrm{cm}$ derinlikteki yüzey toprakların $\% 61.15$ ' $\mathrm{i}$ az kireçli \% 12.88'i kireçli, \% 16.00's1 orta kireçli ve 
\% 9.97'si fazla ve çok fazla kireçli sınıfına girdiğini belirlemişledir. Kireç içeriğinin genelde düşük olması, toprakların kireçsiz ana materyale sahip olması ve yüksek yağışa bağlı olarak karbonatların yıkanması şeklinde açıklanabilir. Eyüpoğlu (1999) az kireçli toprakların, kapladığ 1 alan bakımından en fazla Doğu Karadeniz Bölgesi'nde yer aldığını bildirmektedir.

Araştırma topraklarının EC değerleri yüzeyde $0.04-0.56 \mathrm{dS} \mathrm{m}^{-1}$, yüzey alt1 topraklarda ise 0.05 $0.40 \mathrm{dS} \mathrm{m}^{-1}$ arasında değişmekte olduğu belirlenmiştir (Tablo 5). Topraklarının EC değerleri $4 \mathrm{dS} \mathrm{m}^{-1}$ 'den küçük olup, toprakların tuzluluk yönünden genel anlamda herhangi bir sorunu olmadığı söylenebilir.

Çalışma alanı topraklarının organik madde kapsamları ise yüzey ve derinde sıras1 ile \% 0.61 3.01 ve $\% \quad 0.48-4.24$ arasında değiştiğ saptanmıştır. Ülgen ve Yurtsever (1995)'e göre yapılan sinıflandırmada, yüzey topraklarının \% 12.50'sinin çok az, \%56.2'si az, \% 25.0'ının orta ve \% 6.2'sinin ise iyi düzeyde organik madde içerdiği görülmüştür (Tablo 5). Fakat, Adiloğlu ve Adiloğlu (2006) Trabzon ili Beşikdüzü ve Vakfikebir ilçeleri içerisinde çay tarımı yapılan alanlardan 0-40 cm derinlikte aldıkları 35 toprak örneğinde organik madde içeriklerinin daha yüksek olduklarını belirleyerek, \% 3.48 ile \% 7.88 arasında değiştiğini belirtmişlerdir.

Toprakların dominant bazik katyonları $\mathrm{Ca}$ ve $\mathrm{Mg}$ iyonlarıdır. Çalışmada; 7, 8, 13, 14, 15 ve 16 no'lu toprak örneklerinde derinlik artışı ile toplam değişebilir bazik katyonlarda bir miktar artış olduğu görülmektedir. Bu durum özellikle kil ve organik maddenin alt katlarda birbirleriyle yapmış oldukları bileşik ve tutulma durumlarını gerçekleştirerek, yüzey altı katlarda birikme eğilimi göstermelerinden kaynaklanmaktadır. Dolayısıyla alt katlarda artış eğilimindeki bazik katyonlar $\mathrm{pH}$ üzerine de etkili olmuş ve bir miktar pH'nın da artışını sağlamıştır. Buna karşılık özellikle organik madde miktarı derinlik artışı ile azalma eğiliminde olduğu belirlenmiştir.

Tablo 5. Yüzey ve yüzey altı topraklarına ait fiziks el ve kimyasal analiz sonuçları

\begin{tabular}{|c|c|c|c|c|c|c|c|c|c|c|c|c|}
\hline \multirow{2}{*}{$\begin{array}{c}\text { Örnek } \\
\text { no }\end{array}$} & \multicolumn{4}{|c|}{ Bünye (\%) } & \multirow{2}{*}{$\begin{array}{l}\text { O.M } \\
(\%)\end{array}$} & \multirow[t]{2}{*}{$\mathrm{pH}$} & \multirow{2}{*}{ 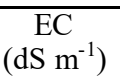 } & \multirow{2}{*}{$\begin{array}{c}\text { Kireç } \\
(\%)\end{array}$} & \multicolumn{4}{|c|}{ Değişebilir katyonlar $\left(\mathrm{cmol} \mathrm{kg}^{-1}\right)$} \\
\hline & Kum & Silt & Kil & Sinif & & & & & $\mathrm{Na}$ & $\mathrm{K}$ & $\mathrm{Ca}$ & $\mathrm{Mg}$ \\
\hline \multicolumn{13}{|c|}{ Yüzey $(0-30 \mathrm{~cm})$} \\
\hline 1 & 72.4 & 14.7 & 12.8 & SL & 1.06 & 5.45 & 0.03 & 0.44 & 0.36 & 0.50 & 18.4 & 3.94 \\
\hline 2 & 74.4 & 16.7 & 8.8 & SL & 1.26 & 4.90 & 0.09 & 0.09 & 0.44 & 0.08 & 13.5 & 3.47 \\
\hline 3 & 77.6 & 14.7 & 7.6 & LS & 1.21 & 4.59 & 0.10 & 0.27 & 0.41 & 0.09 & 12,4 & 5.52 \\
\hline 4 & 72.4 & 18.7 & 8.8 & SL & 1.13 & 4.88 & 0.56 & 0.62 & 0.41 & 0.06 & 17.7 & 3.42 \\
\hline 5 & 63.6 & 25.0 & 11.2 & SL & 2.71 & 3.93 & 0.49 & 0.06 & 0.38 & 0.74 & 6.50 & 4.16 \\
\hline 6 & 64.4 & 20.0 & 15.6 & SL & 2.34 & 4.40 & 0.18 & 0.09 & 0.28 & 0.44 & 9.80 & 4.69 \\
\hline 7 & 54.4 & 26.7 & 18.8 & SL & 0.65 & 4.40 & 0.49 & 0.74 & 0.36 & 0.05 & 13.2 & 5.83 \\
\hline 8 & 61.1 & 24.0 & 14.8 & SL & 2.64 & 4.50 & 0.17 & 0.49 & 0.30 & 0.68 & 12.2 & 1.95 \\
\hline 9 & 62.4 & 22.7 & 14.8 & SL & 1.45 & 4.14 & 0.40 & 0.66 & 0.44 & 0.99 & 10.6 & 2.25 \\
\hline 10 & 51.6 & 27.4 & 20.8 & SCL & 1.99 & 4.77 & 0.22 & 0.27 & 0.34 & 0.41 & 7.30 & 4.25 \\
\hline 11 & 66.4 & 21.0 & 12.5 & SL & 2.81 & 5.63 & 0.09 & 0.97 & 0.33 & 0.13 & 15.0 & 6.09 \\
\hline 12 & 59.1 & 28.0 & 12.8 & SL & 1.31 & 4.99 & 0.16 & 1.31 & 0.34 & 0.22 & 11.9 & 6.61 \\
\hline 13 & 44.4 & 34.7 & 20.8 & $\mathrm{~L}$ & 0.61 & 4.60 & 0.09 & 0.62 & 0.31 & 0.15 & 5.31 & 2.22 \\
\hline 14 & 54.4 & 26.7 & 18.8 & SL & 1.55 & 3.90 & 0,36 & 0.01 & 0.25 & 0.13 & 0.70 & 1.75 \\
\hline 15 & 28.4 & 24.7 & 46.8 & $\mathrm{C}$ & 3.01 & 3.76 & 0,22 & 0.01 & 0.32 & 0.22 & 3.75 & 0.59 \\
\hline 16 & 48.4 & 30.0 & 21.6 & $\mathrm{~L}$ & 1.68 & 4.78 & 0,17 & 0.09 & 0.29 & 0.42 & 9.72 & 5.19 \\
\hline \multicolumn{13}{|c|}{ Yüzey altı $(30-60 \mathrm{~cm})$} \\
\hline 1 & 81.1 & 12.0 & 6.8 & $\overline{\mathrm{LS}}$ & 1.00 & 5.85 & 0.05 & 0.44 & 0.33 & 0.49 & 20.1 & 5.30 \\
\hline 2 & 68.4 & 20.7 & 10.8 & SL & 1.01 & 5.27 & 0.09 & 0.49 & 0.43 & 0.06 & 17.1 & 4.05 \\
\hline 3 & 75.6 & 15.4 & 8.8 & SL & 0.48 & 5.10 & 0.05 & 0.09 & 0.40 & 0.08 & 14.5 & 5.70 \\
\hline 4 & 73.6 & 17.0 & 9.2 & SL & 0.71 & 6.07 & 0.39 & 0.44 & 0.42 & 0.06 & 18.8 & 6.56 \\
\hline 5 & 59.6 & 21.0 & 19.2 & SL & 1.41 & 4.74 & 0.30 & 0.74 & 0.36 & 0.19 & 13.4 & 7.78 \\
\hline 6 & 54.4 & 26.0 & 19.6 & SL & 1.13 & 6.07 & 0.098 & 1.22 & 0.30 & 0.34 & 13.0 & 6.97 \\
\hline 7 & 52.4 & 28.7 & 18.8 & SL & 1.40 & 5.02 & 0.27 & 1.04 & 0.36 & 0.06 & 16.1 & 8.44 \\
\hline 8 & 55.6 & 27.4 & 16.8 & SL & 0.93 & 6.00 & 0.09 & 1.19 & 0.35 & 0.30 & 18.3 & 5.56 \\
\hline 9 & 50.4 & 26.7 & 22.8 & SCL & 3.41 & 4.73 & 0.31 & 0.62 & 0.43 & 0.81 & 16.8 & 11.4 \\
\hline 10 & 47.6 & 25.4 & 26.8 & SCL & 1.41 & 4.77 & 0.22 & 0.44 & 0.43 & 0.27 & 12.0 & 8.47 \\
\hline 11 & 64.4 & 21.0 & 14.5 & SL & 1.65 & 6.32 & 0.12 & 1.66 & 0.36 & 0.13 & 16.6 & 6.59 \\
\hline 12 & 64.4 & 20.7 & 14.8 & SL & 1.21 & 5.79 & 0.08 & 1.79 & 0.31 & 0.11 & 10.8 & 11.7 \\
\hline 13 & 41.1 & 34.0 & 24.8 & $\mathrm{~L}$ & 1.11 & 5.11 & 0.08 & 0.97 & 0.33 & 0.13 & 9.41 & 3.78 \\
\hline 14 & 56.4 & 24.7 & 18.8 & SL & 2.59 & 3.70 & 0.31 & 0.01 & 0.28 & 0.14 & 0.88 & 3.13 \\
\hline 15 & 41.1 & 18.0 & 40.8 & $\mathrm{C}$ & 4.24 & 3.90 & 0.20 & 0.01 & 0.39 & 0.22 & 0.73 & 0.98 \\
\hline 16 & 51.1 & 26.0 & 22.8 & SCL & 2.44 & 5.13 & 0.14 & 0.27 & 0.35 & 0.38 & 13.1 & 4.59 \\
\hline
\end{tabular}


Tablo 6. Yüzey ve yüzey altı topraklarına ait makro ve mikro besin elementi analiz sonuçları

\begin{tabular}{|c|c|c|c|c|c|c|c|}
\hline \multirow{2}{*}{$\begin{array}{c}\text { Örnek } \\
\text { no }\end{array}$} & \multicolumn{3}{|c|}{ Makro besin elementleri $\left(\mathrm{kg} \mathrm{da}^{-1}\right)$} & \multicolumn{4}{|c|}{ Mikro besin elementleri $\left(\mathrm{mg} \mathrm{kg}^{-1}\right)$} \\
\hline & $\overline{\mathrm{N}}$ & $\bar{P}$ & $\overline{\mathrm{K}}$ & $\mathrm{Cu}$ & $\mathrm{Zn}$ & $\mathrm{Fe}$ & $\mathrm{Mn}$ \\
\hline \multicolumn{8}{|c|}{ Yüzey $(0-30 \mathrm{~cm})$} \\
\hline 1 & 1.22 & 16.52 & 7.99 & 1.45 & 0.41 & 98.40 & 2.11 \\
\hline 2 & 1.45 & 11.39 & 1.34 & 0.79 & 0.25 & 91.82 & 0.79 \\
\hline 3 & 1.40 & 15.76 & 1.42 & 0.72 & 0.29 & 69.97 & 1.29 \\
\hline 4 & 1.30 & 13.29 & 1.11 & 2.32 & 0.62 & 106.60 & 2.41 \\
\hline 5 & 3.12 & 39.68 & 12.63 & 0.52 & 0.40 & 96.31 & 1.34 \\
\hline 6 & 2.70 & 16.52 & 7.63 & 0.58 & 0.46 & 117.04 & 1.80 \\
\hline 7 & 0.75 & 10.63 & 0.89 & 0.73 & 0.15 & 67.56 & 17.36 \\
\hline 8 & 3.04 & 19.37 & 11.80 & 0.79 & 0.33 & 116.56 & 1.06 \\
\hline 9 & 1.66 & 12.34 & 17.20 & 0.74 & 0.79 & 127.78 & 2.53 \\
\hline 10 & 2.29 & 5.70 & 7.01 & 0.53 & 0.34 & 58.40 & 1.90 \\
\hline 11 & 3.23 & 7.22 & 2.17 & 1.99 & 0.32 & 95.03 & 2.26 \\
\hline 12 & 1.51 & 3.42 & 3.81 & 1.54 & 0.43 & 133.13 & 1.08 \\
\hline 13 & 0.71 & 5.70 & 2.62 & 1.01 & 0.43 & 103.38 & 12.83 \\
\hline 14 & 1.78 & 1.71 & 2.28 & 0.70 & 0.27 & 27.40 & 0.87 \\
\hline 15 & 3.46 & 1.71 & 3.76 & 0.54 & 1.21 & 105.15 & 3.23 \\
\hline 16 & 1.93 & 4.56 & 7.26 & 1.78 & 0.96 & 95.35 & 1.36 \\
\hline \multicolumn{8}{|c|}{ Yüzey alt1 $(30-60 \mathrm{~cm})$} \\
\hline 1 & 1.15 & 5.32 & 8.46 & 1.27 & 0.29 & 62.42 & 3.04 \\
\hline 2 & 1.17 & 13.10 & 1.11 & 1.15 & 0.26 & 72.70 & 1.86 \\
\hline 3 & 0.55 & 6.08 & 1.47 & 0.73 & 0.19 & 42.66 & 2.22 \\
\hline 4 & 0.82 & 3.80 & 1.11 & 1.97 & 0.61 & 44.10 & 2.43 \\
\hline 5 & 1.62 & 13.29 & 3.26 & 1.52 & 0.44 & 104.19 & 1.50 \\
\hline 6 & 1.30 & 8.73 & 5.98 & 1.10 & 0.43 & 109.17 & 1.36 \\
\hline 7 & 1.61 & 6.08 & 1.00 & 1.74 & 0.33 & 77.52 & 1.69 \\
\hline 8 & 1.07 & 11.58 & 5.12 & 2.69 & 0.43 & 83.78 & 2.18 \\
\hline 9 & 3.92 & 2.85 & 14.47 & 1.63 & 0.56 & 123.14 & 2.13 \\
\hline 10 & 1.62 & 9.68 & 4.68 & 1.57 & 0.36 & 95.83 & 2.30 \\
\hline 11 & 1.89 & 4.18 & 2.14 & 2.21 & 0.57 & 64.18 & 1.97 \\
\hline 12 & 1.40 & 5.13 & 1.98 & 3.52 & 0.55 & 117.20 & 1.76 \\
\hline 13 & 1.28 & 0.95 & 2.17 & 1.88 & 0.50 & 73.82 & 2.49 \\
\hline 14 & 2.98 & 1.90 & 2.45 & 0.58 & 0.22 & 10.39 & 1.08 \\
\hline 15 & 4.87 & 1.52 & 3.98 & 0.46 & 0.66 & 26.27 & 1.82 \\
\hline 16 & 2.81 & 1.90 & 6.48 & 2.38 & 0.94 & 94.71 & 1.95 \\
\hline
\end{tabular}

Yüzey ve yüzey altı olmak üzere toplam 32 toprak örneğinde verimlilik özellikleri bakımından makro besin elementleri içerikleri yönünden Tablo 6 incelendiğinde; toplam azot $(\mathrm{N})$ miktarı yüzey topraklarında $0.71-3.46 \mathrm{~kg} \mathrm{da} \mathrm{da}^{-1}$, yüzey alt1 topraklarda ise 0.55 ile $4.87 \mathrm{~kg} \mathrm{da} \mathrm{da}^{-1}$ olarak bulunmuştur (Tablo 6). Müftüoğlu ve ark. (2010) Artvin, Trabzon ve Rize illerine ait çay tarımı yapılan alanlardan aldıkları 90 adet toprak örneğinde; \% 6.66'sının orta, \% 38.88'inin fazla ve \% 54.44'ünün ise çok fazla azot içeriğine sahip olduğu belirlemiş lerdir.

Bölge çay topraklarının alınabilir $P$ içeriklerinin yüzeyde $1.71-39.68 \mathrm{~kg} \mathrm{da}^{-1}$ arasında, yüzey altında ise 0.95 ile $13.29 \mathrm{~kg} \mathrm{da}^{-1}$ arasında değiştiği belirlenmiştir (Tablo 6). Yüzey topraklarında \% 12.50'sinin çok az, \% 25.00'inin az, \% 6.25'inin orta, \% 12.50'sinin yüksek ve \% 43.75'inin ise çok yüksek düzeyde $\mathrm{P}$ içerdiği anlaşılmıştır. Araştırma topraklarının alınabilir P içerikleri incelendiğinde oransal olarak yarıdan fazlasının (\% 56.25) yüksek ve çok yüksek düzeyde olduğu, derinde ise bu oranın (\% 75.00) ile tersi bir durum göstererek çok az ve az olarak ortaya çıktığ1 gözlemlenmiştir. Bu durum, her ne kadar fosforlu gübre uygulaması yapılsa bile, büyük çoğunluğunu eğimli arazilerin oluşturduğu çay bahçelerinde; eğim ve buna bağlı olarak toprak derinliğinin az oluşu nedeniyle uygulanan gübrenin toprak altına verilememesi, toprağa karıştırılmadan yüzeye verilen fosforlu gübrelerin de yüzeyden kolayca akıp gitmesinin bir sonucu olarak karşımıza çıkmaktadır. Özyazıcı ve ark. (2016), Orta ve Doğu Karadeniz Bölgesi tarım topraklarının alınabilir $\mathrm{P}$ içeriklerinin $0.1-129.7 \mathrm{~kg}$ $\mathrm{P}_{2} \mathrm{O}_{5} \mathrm{da}^{-1}$ aras ında değiştiğini belirlemişlerdir. Aynı araştırmada bölge geneli itibariyle; toprakların $\%$ 35.71'inin çok az, \% 23.12'sinin az, $\%$ 10.14'ünün orta, \% 5.53'ünün yüksek ve $\%$ 25.50'sinin ise çok yüksek düzeyde fosfor içerdiğini bildirmiş lerdir.

Toprakların ekstrakte edilebilir $\mathrm{K}$ içerikleri yüzeyde ve derinde sirasiyla $0.89-17.20$ ve 1.0 $14.47 \mathrm{~kg} \mathrm{~K}_{2} \mathrm{O} \mathrm{da} \mathrm{da}^{-1}$ arasında değişiklik göstermiştir 
(Tablo 6). Ülgen ve Yurtsever (1995)'e göre toprakların $\mathrm{K}$ değerleri $20 \mathrm{~kg} \quad \mathrm{da}^{-1}$ 'dan düşük olmas1 durumunda çok az olarak sinıflandırmaktadır. Alınan toprak örneklerinin yüzeylerinde ve derinde ekstrakte edilebilir $\mathrm{K}$ bakımından çok az sınıfta olarak değerlendirilmektedir. Toprakların ekstrakte edilebilir $\mathrm{K}$ miktarlarının düşüklüğü, toprak bünyesi ve pH'sı ile ilişkili olduğu düşünülmektedir. Bayraklı (1998), özellikle hafif tekstürlü ve ileri derecede ayrışmış, parçalanmış asit topraklarda katyon tutma kapasitesi çok düşük olduğundan, potasyumun yıkanarak kaybolma tehlikesinin fazla olduğunu bildirmektedir. Toprakların büyük çoğunluğunun $\mathrm{K}$ içeriklerinin düşük düzeyde olması söz konusu topraklarda yetiştirilen ürünlerde $\mathrm{K}$ noksanlığının ortaya çıkmasina neden olacaktır. Bu nedenle, K noksanlığ1 bulunan tarla topraklarında, yüksek verim ve kaliteli ürün almak için potasyumlu gübrelemeye önem verilmelidir (Özyazıcı ve ark., 2016). Ayrıca, Müftüoğlu ve ark. (2010) Artvin, Trabzon ve Rize illerine ait çay tarımı yapılan alanlardan aldıkları 90 adet toprak örneklerinde potasyum içeriklerinin \% 73.26'sının az ve orta, $\%$ 26.66'sının ise fazla olduğunu belirlemişlerdir.

Çalışma alanından alınan yüzey ve yüzey altı toprakların mikro besin element içerikleri Tablo 6, elementlerin sınır aralık değerleri ise Tablo 7'de verilmiştir.

Tablo 6 incelendiğinde $\mathrm{Cu}$, yüzey toprakları içerisinde aluviyal ana materyal üzerinde oluşmuş taban arazide yer alan \% 63.6 oranında kum içeren 5 numaralı örnekte $0.52 \mathrm{mg} \mathrm{kg}{ }^{-1}$ iken, yine aynı bünyeye sahip sırt fizyografik üzerinde oluşmuş 11 no'lu toprak örneğinde $1.99 \mathrm{mg} \mathrm{kg} \mathrm{kg}^{-1}$ olarak belirlenmiştir. Yüzey topraklarının ortalama $\mathrm{Cu}$ miktarı $1.04 \mathrm{mg} \mathrm{kg}^{-1}$ olduğu görülmektedir. Yüzey alt1 topraklarda ise $\mathrm{Cu} 0.46-3.52 \mathrm{mg} \mathrm{kg}^{-1}$ arasinda değişmektedir. Lindsay ve Norvell (1978) göre; gerek yüzey ve gerekse de yüzey altı toprakların $\mathrm{Cu}$ içerikleri $0.2 \mathrm{mg} \mathrm{kg} \mathrm{kg}^{-1}$ 'dan yüksek olması nedeniyle yetersizlik görülmemektedir (Tablo 7).

Toprakların Fe içerikleri yüzeyde 27.40 ile $133.13 \mathrm{mg} \mathrm{kg}^{-1}$ arasında değişmekte olup, ortalama $94.36 \mathrm{mg} \mathrm{kg}{ }^{-1}, 30-60 \mathrm{~cm}$ derinlikte ise ortalama $75.13 \mathrm{mg} \mathrm{kg}{ }^{-1}$ olarak belirlenmiştir (Tablo 6). Tablo 7'e göre toprakların Fe içerikleri her iki derinlik içinde yüksek olduğu görülmektedir.

Yüzey ve yüzey altı toprak örneklerinde $\mathrm{Zn}$ içeriği yönünden Anonymous (1990b)'a göre incelendiğinde 0.15 ile $1.21 \mathrm{mg} \mathrm{kg} \mathrm{kg}^{-1}$ arasinda değişmektedir. $\mathrm{Bu}$ durum toprakların $\mathrm{Zn}$ içerikleri yönünden çok düşük ile yeterli sınıflar arasında değiştiğini göstermektedir. Yüzey altı topraklara bakıldığında ise $\mathrm{Zn}, 0.19$ ile $0.94 \mathrm{mg} \mathrm{kg}^{-1}$ ile aynı sınıf aralıklarına sahip olduğu belirlenmiştir.

Toprakların $\mathrm{Mn}$ içerikleri ise yüzey topraklarında 0.79 ile $17.36 \mathrm{mg} \mathrm{kg} \mathrm{kg}^{-1}$, yüzey alt1 topraklarda ise 1.08 ile $3.04 \mathrm{mg} \mathrm{kg} \mathrm{kg}^{-1}$ arasında değişmekte olduğu belirlenmiştir (Tablo 6). Manganda çinkoda olduğu gibi topraklarda yüzeyde çok düşük ve yeter düzeyde iken, yüzey altında çok düşük ve düşük düzeyde olduğu tespit edilmiştir. Adiloğlu ve Adiloğlu (2006), Trabzon ilinde çay yetiştirilen topraklarından alınan örneklerde yapmış oldukları çalışmada toprakların mikro besin elementlerin içeriklerine yönelik benzer sonuçlar belirlemiş lerdir.

Tablo 7. Mikro elementler, yöntemlerive sınır aralık değerleri

\begin{tabular}{lll}
\hline Mikro elementler & Limit değerler $\left(\mathrm{mg} \mathrm{kg}^{-1}\right)$ & Sinif \\
\hline Fe (DTPA) & $<2.5$ & Düşük \\
(Lindsay ve Norvell, 1978) & $2.5-4.5$ & Orta \\
& $>4.5$ & Yüksek \\
\hline Cu (DTPA) & $<0.2$ & Yetersiz \\
(Lindsay ve Norvell, 1978) & $>0.2$ & Yeterli \\
\hline & $<0.2$ & Çok düşük \\
Zn(DTPA) & $0.2-0.7$ & Düşük \\
(Anonymous, 1990) & $0.7-2.4$ & Yeterli \\
& $2.4-8.0$ & Yüksek \\
& $>8.0$ & Çok yüksek \\
\hline & $<4$ & Çok düşük \\
Mn(DTPA) & $4-14$ & Düşük \\
(Anonymous, 1990) & $14-50$ & Yeterli \\
& $50-170$ & Yüksek \\
& $>170$ & Çok yüksek \\
\hline
\end{tabular}




\section{Sonuçlar}

Anonymous (2003) kayıtlarına göre, Türkiye'nin gerek üretim alanı ve gerekse de miktarı açısından dünyada çay konusunda önemli bir yere sahip olduğu görülmektedir. Bunun temel sebeplerinden birisi, çay bitkisinin toprak, iklim gibi özel ekolojik isteklere sahip olmasindan kaynaklanmaktadır. $\mathrm{Bu}$ nedenle, ekonomik ve ekolojik anlamda sürdürülebilir bir çay üretimin yapılabilmesi, ancak çay bitkisinin yetiştiriciliği yapılan alanların karakteristiklerinin belirlenmesi ve bu özelliklere göre bir yönetim gerçekleştirilmesiyle mümkün olmaktadır.

Çataklı Havzası'nın sağ yakasında dere kenarı düzlük, alt yamaç, üst yamaç, omuz ve tepe üstü düzlük olarak farklı kot seviyeleri ve fizyografik üniteler şeklinde belirlenen çalışma alanı araştırma sonuçlarına göre, toprakların bünyesi genellikle kum içeriğinin yüksek olması nedeniyle kumlu tın ve tın bünyeye sahiptir. $\mathrm{Bu}$ toprakların büyük çoğunluğunun organik maddece fakir olduğu gözlemlenmiştir. Çay tarımı yapılan alanlarda istenilen $\mathrm{pH}$ düzeyinin 4.5-6.0 arasında olduğu düşünülürse, çalışma alanı toprakları genellikle kuvvetli asit özellik göstermektedir. $\mathrm{Bu}$ asitlik durumunun kademeli olarak yıllar içerisinde düzeltilebilmesi için sülfatlı gübrelemeden vazgeçilip, hayvan gübresi ile birlikte toprak analiz sonuçlarına bağlı olarak kireç uygulaması yapılmalıdır. Yine analiz sonuçları dikkate alındığında toprakların makro besin elementlerinden azot içerikleri yönünden toprakların eksikliği bulunmamaktadır. Fakat bölgenin yüksek miktarda yağış aldığ1 düşünülürse, azotun topraktan yıkanıp uzaklaşan bir element olması nedeniyle gübrelemede göz önünde bulundurulmalıdır. Bölge toprakları P içeriği bakımından genellikle orta düzeyde olmasına karşın, $\mathrm{K}$ içeriği bakımından fakirdir. Toprakların mikro besin elementleri yönünden ise $\mathrm{Fe}$ ve $\mathrm{Cu}$ yönünden bir problem bulunmamasina karşın, özellikle $\mathrm{Zn}$ ve Mn içerikleri yönünden yer yer yetersiz oldukları belirlenmiştir. $\mathrm{Bu}$ nedenle özellikle çay bitkisinin yapraktan çinko ve mangan gübrelemelerinin de yapılması gerekmektedir.

\section{Kaynaklar}

Adiloğlu, A., Adiloğlu, S., 2006. An investigation on nutritional status of tea (Camellia sinensis L.) grown in eastern blacksea region of Turkey. Pakistan Journal of Biological Sciences, 9(3): 365-370.

Anonim, 2016. Trabzon Ortalama Değerler Bülteni, Trabzon. http://www.trabzon.mgm.gov.tr/ (Erişim tarihi: 06.10.2016).

Anonymous, 1990a. Analytical for Atomic Absorption Spectrophotometry. Perkin Elmer, Norwalk, Connecticut, USA.
Anonymous, 1990b. Micronutrient, assessment at the country level: An international study. Food and Agriculture Organization of the United Nations, Soil Bulletin by Mikko Sillanpaa, Rome.

Anonymous, 1992. Soil Survey Staff, Procedures For Collecting Soil Samples and Methods of Analysis For Soil Survey. Soil Survey Investigation Report I. U.S. Goverment. Print. Office, Washington D.C.

Anonymous, 2003. Trade Reforms and Food Security. Food and Agriculture Organization of the United Nations, Rome.

Anonymous, 2015. World Tea Production and Trade Current and Future Development. By Kaison ChangSecretary. Food and Agriculture Organization of the United Nations, Rome.

Bayrakl1, F., 1998. Toprak Kimyası. Ondokuz May1s Üniversitesi, Ziraat Fakültesi Ders Kitabı, No: 26, 1. Baskı, Samsun.

Bouyoucos, G.J., 1951. A Recalibration of the hydrometer method for making mechanical analysis of soil. Agronomy Journal, 43: 434-438.

Bray, R.H., Kurtz, L.T., 1945. Determination of total, organic, and available forms of phosphorus in soils. Soil Science, 59(1): 39-46.

Eden, T., 1976. Tea thirt edition tropical agriculture series longman group limited. London.

Eyüpoğlu, F., 1999. Türkiye Topraklarının Verimlilik Durumu. T.C. Başbakanlık Köy Hizmetleri Genel Müdürlüğü, Toprak ve Gübre Araştırma Enstitüsü Yayınları, Genel Yayın No: 220, Teknik Yayın No: T-67, Ankara.

Kacar, B., 1984. Çayın Gübrelenmesi. Çay İşletmeleri Genel Müdürlüğü, Çay-Kur Yay ını No: 4, Ankara.

Kacar, B., 2010. Çay Bitkisi, Biyokimyası, Gübrelenmesi ve İșleme Teknolojisi. Nobel Yayın Evi, İstanbul.

Lindsay, W.L., Norvell, W.A., 1978. Development of a DTPA soil test for zinc, iron, manganese and copper. Soil Science Society of America Journal, 42(3): 421428.

Mulla, D.J., McBratney, A.B., 2000. Soil Spatial Variability. In: M.E. Sumner (Ed.), Handbook of Soil Science, Boca Raton, FL: CRC Press, pp. 321352 .

Müftüoğlu, N.M., 1990. Doğu Karadeniz Çay Tarım Topraklarının Mikrobiyolojik Dinamiği ve Toprak Asitliliğini Etkileyen Biyolojik Faktörler. Çay İşletmeleri Genel Müdürlüğü, Çay-Kur Yayını, No: 12, Rize.

Müftüoğlu, N.M., Yüce, E., Turna, T., Kabaoğlu, A., Özer, S.P., Tanyel, G., 2010. Çay tarımı yapılan alanların bazı toprak ve bitki özelliklerinin değerlendirilmesi. Ege Üniversitesi Ziraat Fakültesi Dergisi, Özel Say1, 309-316.

Nelson, D.W., Sommers, L.E., 1982. Total Carbon, Organic Carbon, Organic Matter. In: AL Madison (Ed.), Methods of Soil Analysis, Part 2, $2^{\text {nd }}$ Ed., Chemical and Microbiological Properties. Wisconsin, USA: American Society of Agronomy Inc, pp. 539-579. 
Nelson, R.E., 1982. Carbonate and gypsum. Chemical and Microbiological Properties. In: Methods of Soil Analysis, Part II, Agronomy No 9, (2 ${ }^{\text {nd }}$ ed.), Madison, pp. 181-197.

Olsen, S.R., Cole, C.V., Watanabe, F.S., Dean, L.A., 1954. Estimation of available phosphorus in soils by extraction with sodium bicarbonate. USDA Circular No: 939, U.S Goverment Print Office, Washington, D.C.

Özuygur, M., Ateşalp, M., Börekçi, M., 1974. Doğu Karadeniz topraklarının kireç ihtiyaçlarının tayininde uygulanacak metotlar ve kireçleme malzemeleri üzerine bir araştırma. TÜBİTAK Tarım ve Ormancılık Grubu Tübitak Yayınları No: 23. TOAG Seri No: 48, Ankara.

Özyazıcı, G., Özyazıcı, M.A., Özdemir, O., Sürücü, A., 2010. Some physical and chemical properties of tea grown soils in Rize And Artvin provinces. Anadolu Journal of Agricultural Sciences, 25(2): 94-99.

Özyazıcı, M.A., Dengiz, O., Aydoğan, M., 2013. Çay Yetiştirilen Tarım Topraklarının Reaksiyon Değişimleri ve Alansal Dağılımları. Toprak Su Dergisi, 2(1): 23-29.

Özyazıcı, M.A., Dengiz, O., Aydoğan, M., Bayraklı, B., Kesim, E., Urla, Ö., Yıldız, H., Ünal, E., 2016. Orta ve Doğu Karadeniz Bölgesi tarım topraklarının temel verimlilik düzeyleri ve alansal dağılımları. Anadolu Tartm Bilimleri Dergisi, 31(1): 136-148.

Özyazıc1, M.A., Özyazıcı, G., Dengiz, O., 2011. Determination of micronutrients in tea plantations in
The Eastern Black Sea Region, Turkey. African Journal of Agricultural Research, 6(22): 5174-5180.

Özyazıcı, M.A., Sağlam, M., Dengiz, O., Erkoçak, A., 2014. Çay tarımı yapılan topraklara yönelik faktör analizi ve jeoistatistik uygulamaları: Rize ili örneği. Toprak Su Dergisi, 3(1): 12-23.

Rhoades, J.D., 1986. Cation exchang ecapacity. Chemicaland Microbiological Properties. In: Methods of Soil Analysis, Part II., ASA and SSSA AgronomyMonograph No 9 (2nd ed), Madison, pp. 149-157.

Richards, L.A., 1954. Diagnosis and Improvoment of Salineand Alkaline Soils. U.S.A: U.S. Department of Agriculture, Handbook 60.

Sharma, V.S., Ranhanathan, V., 1985. Theworld of teatoday. Outlook an Agriculture, 14(1): 35-36.

Tekeli, S.T., 1976. Çay Yetiştirme, İşleme, Pazarlama. Dönüm Yayınları 5, Ankara Basım ve Ciltevi, Ankara.

Ülgen, N., Yurtsever, N., 1995. Türkiye Gübre ve Gübreleme Rehberi (4. Bask1). T.C. Başbakanlık Köy Hizmetleri Genel Müdürlüğu Toprak ve Gübre Araştırma Enstitüsü Müdürlüğ̈̈ Yayınları, Genel Yay in No: 209, Teknik Yayınlar No: T.66, Ankara.

Wilding, L.P., 1985. Spatial variability: It's documentation, accommodation and implication to soil surveys. In: DR Nielsenand J Bouma (Eds.), Soil Spatial Variability, Pudoc, Wageningen, pp: 166-194. 